\title{
Evaluation of Barley Genotypes against Spot Blotch Disease in Inner Tarai Region of Nepal
}

\author{
Subash Subedi ${ }^{1 @}$, Sarasawati Neupane $^{1}$, Sukbahadur Gurung $^{2}$, Arjun Raymajhi ${ }^{3}$ and Lokendra Oli ${ }^{1}$ \\ ${ }^{1}$ Senior scientist, Nepal Agricultural Research Council, National Maize Research Program, Rampur, Chitwan \\ Nepal; @: subedi.subash1@gmail.com ORCID: https://orcid.org/0000-0003-3739-1773; SN: \\ sarusanu2017@gmail.com; LN:lokendraolinarc@gmail.com \\ ${ }^{2}$ Scientist, Hill Crops Research Program, Kabre, Dolakha, Nepal; s.b.syangbo@gmail.com \\ ${ }^{3}$ Agriculture and Forestry University, Rampur, Chitwan, Nepal; rmcarjun.rocket1994@gmail.com
}

Received 07 Sept 2019, Revised 27 Dec 2019, Accepted 14 Feb 2020, Published 17 March 2020

Scientific Editors: Bedanand Chaudhary, Jiban Shrestha

Copyright $(2020$ NARC. Permits unrestricted use, distribution and reproduction in any medium provided the original work is properly cited.

The authors declare that there is no conflict of interest.

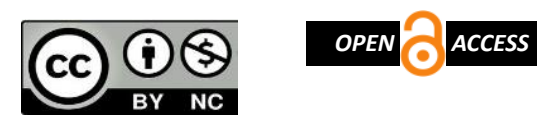

Licensed under the Creative Commons Attribution NonCommercial 4.0 International (CC BY-NC 4.0)

\section{ABSTRACT}

Spot blotch caused by Bipolaris sorokiniana (Sacc. in Sorok.) Shoem. is an important disease of barley (Hordeum vulgare L.). A total of 126 barley genotypes received from Hill Crops Research Program, Kabre, Dolakha having SoluUwa as a susceptible check and Bonus as a resistant check were evaluated as barley disease screening nursery (BDSN) under natural epiphytotic condition at National Maize Research Program, Rampur, Chitwan during winter seasons of 2017 and 2018. The nursery was planted in augmented design. The resistant and susceptible checks were repeated and planted after each 10 tested entries. The unit plot size was 2 rows of one meter length for each genotype planted continuously with $25 \mathrm{~cm}$ row to row spacing. The seed rate was $100 \mathrm{~kg} / \mathrm{ha}$. The recommended fertilizer dose of 23:30:0 N:P $\mathrm{P}_{2} \mathrm{O}_{5}: \mathrm{K}_{2} \mathrm{O} \mathrm{kg} / \mathrm{ha}$ was applied. The double digit scale (00 to 99) was used to measure overall foliar infection on the whole plant during flowering, soft dough and hard dough stages. Other agronomic practices were followed as per recommendation. Genotypes B86019-1K-3K-0K3, ACC 2087, ACC 2441, ACC GHv-06816, ACC 1597, ACC 1612, ACC 2059 and ACC 2032 were resistant against spot blotch disease. Similarly, 32 barley genotypes were moderately resistant and rest of the tested genotypes were susceptible to the disease. The selected resistant barley genotypes can be used in crossing program and/or promoted for further testing to develop spot blotch resistant varieties for inner Tarai region of Nepal.

Keywords: Barley, Bipolaris sorokiniana, resistant genotypes, spot blotch

\section{सारांश}

जौमा लाग्ने थोप्ले धब्बे (स्पट व्लच) एक महत्वपूर्ण रोग हो जुन बाईपोलारिस सोरोकिनिएना नामक ढुसीले गर्दा लागदछ। रोग कम लाग्ने तथा यसको आक्रमण सहन सक्ने जातहरुको छनौट तथा बिकाशको लागि, पहाडी बाली अनुसन्धान कार्यक्रम, काब्रे, दोलखाबाट प्राप्त १२६ वटा जौको जातहरुलाई लगातार सन् २०१७ र २०१६ को हिउदे मौसममा, राष्ट्रिय मकैबाली अनुसन्धान कार्यक्रम, रामपुर, चितवनको अनुसन्धान ब्लकमा जौ रोग अबरोधक जात छनोट नर्सरी परिक्षणहरु संचालन गरिलगाइएको थियो जसमा बोनस भन्ने जातलाई रोग प्रतिरोधी क्षमता बढ़ी भएको (रेजिस्टेंट चेक) साथै सोलु उवा भन्ने जातलाई रोग संक्रमित ( ससेस्पटिबल चेक) को रुपमा राखिएको थियो। उक्त परिक्षण नर्सरी आगुमेन्टेड ढाँचामा ब्यबस्थित गरिएको थियो जसमा रेजिस्टेंट चेक र ससेस्पटिबल चेकमा राखिएका जातहरुलाइ प्रत्येक 90 वटा जौका जातहरु पछि दोहोर्याएर रोपिएको थियो। प्रत्येक जौको जातहरुलाइ एक मिटर लामो दुइ वटा लाइनको प्लटहरुमा, एक लाइन देखि अर्को लाइन बिचको दुरी २५ से.मि. तथा बिरुवा देखि बिरुवा बीचको दुरी लगातार कायम हुने गरि लगाइएको थियो। मलखादको मात्रा २०:३०:० नाइट्रोजन : फस्फोरस : पोटाश के.जी./हे. तथा बिड दर 900 केजी/हे कायम गरिएको थियो भने अन्यवाली व्यवस्थापन सम्बन्धी कार्यहरु सीफारीस अनुसार गरीएको थियो। रोग सम्बन्वी आंकडाहरु, विरुवाको सम्पूर्ण पातहरुमा लागेको रोगको, दोहोरो अंकमापक (०० देखि ९९) पद्धति मार्फत वालीको फुल फुल्ने, दाना लाग्ने र दाना पुष्ट्नि वेलागरि तीन पटक लिइएको थियो । रोग सम्बन्धी आंकडाहरुको विश्लेषण गर्दा, वी६६०१९-१के-३के-०के३, ए.सी.सी.२०६७, ए. सी.सी.२४४१, ए.सी.सी.जी.एच.भी-०६६१६, ए.सी.सी.१५९७, ए.सी.सी.१६१२, ए. सी.सी.२०४९ र ए.सी.सी.२०३२ जौका जातहरु रोग अवरोधक जातहरुको रुपमा पाइयो भने ३२ वटा जातहरु रोग सहन सक्ने र वांकी जातहरु रोग संक्रमित जातहरुको रुपमा रेकर्ड गरीयो। यस परिक्षणको नतिजाबाट प्राप्त रोग अवरोधक जातहरु नेपालको भित्रिमधेश क्षेत्रमा थोप्ले धब्बे (स्पट व्लच) रोग अवरोधक जातहरुको रुपमा बिकास गर्नको लागि वालीप्रजनन अर्त्तगतको कसीड़न कार्यकमको लागि उपयोगी सिद्द हुने छन । 


\section{INTRODUCTION}

Barley (Hordeum vulgare L.), a member of the grass family poaceae, self-pollinated and diploid species $(2 n=14)$ is a major cereal grain grown in temperate climates globally. It is an oldest cultivated crop and currently the fifth most important cereal crop of Nepal both in areas and production, after rice, maize, wheat and millet (MoAD 2017) and the fourth in case of India and the World, (Singh et al 2014). In 2016, barley ranked $4^{\text {th }}$ among grains in quantity produced (141 million tonnes) behind maize, rice and wheat and Russia was the top producer (FAOSTAT 2017). Barley is one of the first cultivated grains, particularly in Eurasia as early as 10,000 years ago (Zohary and Hopf 2000). It is grown from the Tarai, up to an elevation of $4000 \mathrm{~m}$ in Nepal, but is a staple food crop mainly in the hills and mountains in the west of the country (Riley and Singh 1991). In Nepal, during 2016/17 it was cultivated in the total area of 27,370 ha and total production was 30,510 t with productivity of $1,115 \mathrm{~kg} / \mathrm{ha}$ (MoAD 2017). There are two types of barley based on spike morphology: two-row and six-row barley and three types based on growth habit: winter, spring and facultative types (Poehlman 1994). It is also used as animal fodder, as a source of fermentable material for beer and certain distilled beverages, and as a component of various health foods. However, crop suffers significant yield losses from biotic stresses. Among biotic stresses, Spot blotch caused by the ascomycetous fungus Bipolaris sorokiniana [Sacc. in Sorok.] Shoem. (Teleomorph: Cochliobolus sativus (Ito and Kuribayashi) Drechs. ex Dastur), is a serious fungal disease with wide geographical distribution. This fungus is also the causal agent of common root rot and black point of wheat and barley (Gupta et al 2017, Wiese 1987). Spot blotch is a seed borne fungal disease, mostly found under warm wet conditions mainly in the Tarai and inner Tarai region. The pathogen survives in infected stubble and is also capable of surviving as a saprophyte on dead tissues (Manandhar et al 2016). Seedling infection causes blight, which frequently results in pre- or post-emergence seedling death. Spot blotch now has emerged as a serious concern for cultivation of barley, wheat and other cereals in the warmer parts of the world (Mathre 1997), and several countries of Asia (Sharma et al 2004). It reduces yield as well as quality of barley grain (Mathre 1997). High temperature and high relative humidity are most favorable for the outbreak of this pathogen (Aggarwal et al 2000). In view of the continued threat of the spot blotch, urgent need to identify and develop genetically improved germplasm for spot blotch resistance and agronomic features. In this study, barley genotypes were evaluated to identify promising sources for spot blotch resistance and important yield contributing traits to facilitate the future barley breeding program.

\section{MATERIALS AND METHODS}

A total of 126 barley genotypes including Solu Uwa as a susceptible and Bonus as a resistant check received from Hill Crops Research Program, Kabre, Dolakha were evaluated in barley disease screening nursery (BDSN) under natural epiphytotic condition at National Maize Research Program, Rampur, Chitwan during winter seasons of 2017 and 2018. The nursery was planted in augmented design. The resistant and susceptible checks were repeated and planted after 10 tested entries. The unit plot size was 2 rows of one meter length for each genotype. The genotype was sown continuously with $25 \mathrm{~cm}$ row to row spacing. The seed rate was $100 \mathrm{~kg} / \mathrm{ha}$. The recommended fertilizer dose of 23:30:0 N: $\mathrm{P}_{2} \mathrm{O}_{5}: \mathrm{K}_{2} \mathrm{O} \mathrm{kg} /$ ha was applied. The nursery was planted in first week of December for both the years 2017 and 2018. All the recommended agronomical and cultural practices were followed for raising the good crop. Observations of disease severity were recorded at flowering, soft dough and hard dough stages. For data collection 20 plants were randomly selected and tagged in each genotype of 2 rows. The double digit scale (00 to 99), developed by the modification of Saari and Prescott (1975) Scale was used to measure overall foliar infection on the whole plant on the basis of two digit, where the first digit (D1) indicates disease progress in canopy height from the ground level, the second digit (D2) refers to severity of the disease based on diseased leaf area (Nagarajan 1998). D1 represents vertical extent and D2 represents horizontal extent. Both D1 and D2 gradations were expressed in 1-9 scale (Mujeeb-Kaji et al 1996).

James (1974) explained severity as the area of plant tissue affected by disease, whereas Horsfall and Cowling (1978) expand the definition to area and volume of plant tissue affected. Percentage disease severity can be calculated by the following formula: 
Disease Severity $(\%)=(\mathrm{D} 1 / 9) \times(\mathrm{D} 2 / 9) \times 100$

Where, D1 = first digit / height of infection, D2= second digit / severity of infection

\begin{tabular}{|c|c|c|c|}
\hline \multicolumn{2}{|c|}{ Scale for height of infection } & \multicolumn{2}{|c|}{ Scale for severity of infection } \\
\hline \multicolumn{2}{|c|}{$1=$ lowest leaf } & \multicolumn{2}{|l|}{$1=10 \%$ coverage } \\
\hline \multicolumn{2}{|c|}{$2=$ second leaf from base } & \multicolumn{2}{|l|}{$2=20 \%$ coverage } \\
\hline \multicolumn{2}{|c|}{$3-4=$ second leaf up to below middle of plant } & \multicolumn{2}{|l|}{$3=30 \%$ coverage } \\
\hline \multicolumn{2}{|c|}{$5=$ up to middle leaf of plant } & \multicolumn{2}{|l|}{$4=40 \%$ coverage } \\
\hline \multicolumn{2}{|c|}{$6-8=$ from center of plant to below of the flag leaf } & \multicolumn{2}{|l|}{$5=50 \%$ coverage } \\
\hline \multirow{4}{*}{\multicolumn{2}{|c|}{$9=$ up to flag leaf }} & \multicolumn{2}{|l|}{$6=60 \%$ coverage } \\
\hline & & \multicolumn{2}{|l|}{$7=70 \%$ coverage } \\
\hline & & \multicolumn{2}{|l|}{$8=80 \%$ coverage } \\
\hline & & \multicolumn{2}{|c|}{$9=$ more than $90 \%$ coverage } \\
\hline \multicolumn{4}{|c|}{ Disease scoring scale (Singh et al 2014) } \\
\hline Scale & Reaction & & Host response \\
\hline 1 & 00 score & & Immune \\
\hline 2 & 01-14 score; lesions absence or small with & & Resistant \\
\hline 3 & $15-35$ score; lesions small but with some c & & Moderately resistant \\
\hline 4 & $\begin{array}{l}36-55 \text { score; lesions large with extens } \\
\text { coalescence }\end{array}$ & sis but little or no & Moderately susceptible \\
\hline 5 & 56-79 score; lesions large and coalescence & rosis & Susceptible \\
\hline 6 & $>79$ score; lesions large and extensive coal & ith severe chlorosis & Highly susceptible \\
\hline
\end{tabular}

To assess the effect of different weather factors on the development of spot blotch disease of barley, the crop was allowed to develop normal infection under natural epiphytotic condition. The disease severity was recorded at weekly interval during flowering, soft dough and hard dough stages. The data on weather parameters viz, maximum temperature, minimum temperature, relative humidity and rainfall during the disease assessment period was recorded. The correlation and regression analysis among abiotic factors (Meteorological parameters) on the development of spot blotch disease was calculated.

The multiple linear regression model was used as follows;

$$
y=\beta_{0}+\beta_{1} w_{1}+\beta_{2} w_{2}+\beta_{3} w_{3}+\beta_{4} w_{4}
$$

Where $y=$ Response or dependant variable ie disease severity

$\beta_{0}=$ Constant, $\beta_{(1-4)}=\mathrm{Un}$-standardized coefficient for each predictor variables

$w_{1}=$ Average Max temperature in ${ }^{\circ} \mathrm{C}$ (During disease assessment period)

$w_{2}=$ Average Min temperature in ${ }^{\circ} \mathrm{C}$ (During disease assessment period)

$w_{3}=$ Total rainfall in $\mathrm{mm}$ (During disease assessment period)

$w_{4}=$ Average relative humidity $(\%)$ (During disease assessment period)

The significance of multiple correlation coefficients $(\mathrm{R})$ was determined by analysis of variance and the significance of partial regression coefficient was determined by t-test.

\section{RESULTS}

During 2017-2018, out of 126 genotypes, 14 genotypes were resistant, 34 were moderately resistant, 74 were susceptible and 8 genotypes were highly susceptible to the disease (Table 1, Figure 1). 
Table 1. Disease scores of barley genotypes against Bipolaris sorokiniana at National Maize Research Program, Rampur, Chitwan, Nepal during 2018 Winter

\begin{tabular}{|c|c|c|c|c|}
\hline SN & Disease Response & $\begin{array}{l}\text { Double } \\
\text { Digit Scale }\end{array}$ & Barley Genotypes & $\begin{array}{l}\text { No of } \\
\text { genotypes }\end{array}$ \\
\hline 1. & Immune (I) & 00 & Nil & \\
\hline 2. & Resistant (R) & $01-14$ & $\begin{array}{l}\text { B86019-1K-3K-0K3, ACC\#2087, } \\
\text { ACC\#2476, ACC\#2496, } \\
\text { 0K,ACC\#GHv-06816, ACC\#1612, ACC\#1597, } \\
\text { ACC\#2087, ACC\#2441, ICB-105969-3-2-0K, } \\
\text { ACC\#2079, XVEoLA-28 }\end{array}$ & 14 \\
\hline 3. & $\begin{array}{l}\text { Moderately } \\
\text { Resistant (MR) }\end{array}$ & $15-35$ & 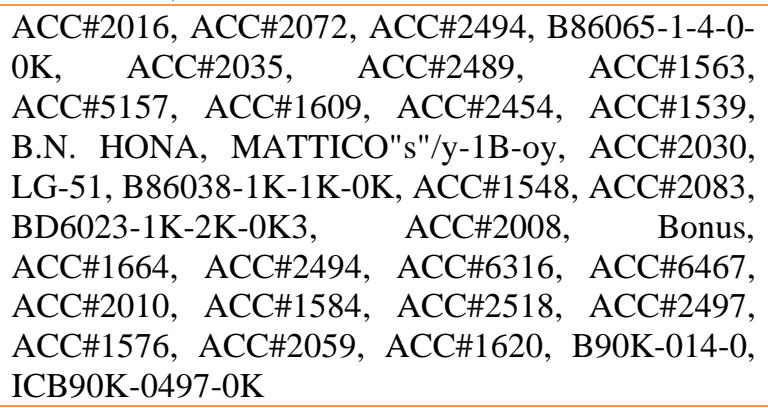 & 34 \\
\hline 4. & $\begin{array}{l}\text { Moderately } \\
\text { Susceptible (MS) }\end{array}$ & $36-55$ & Nil & \\
\hline 5. & Susceptible (S) & $56-79$ & 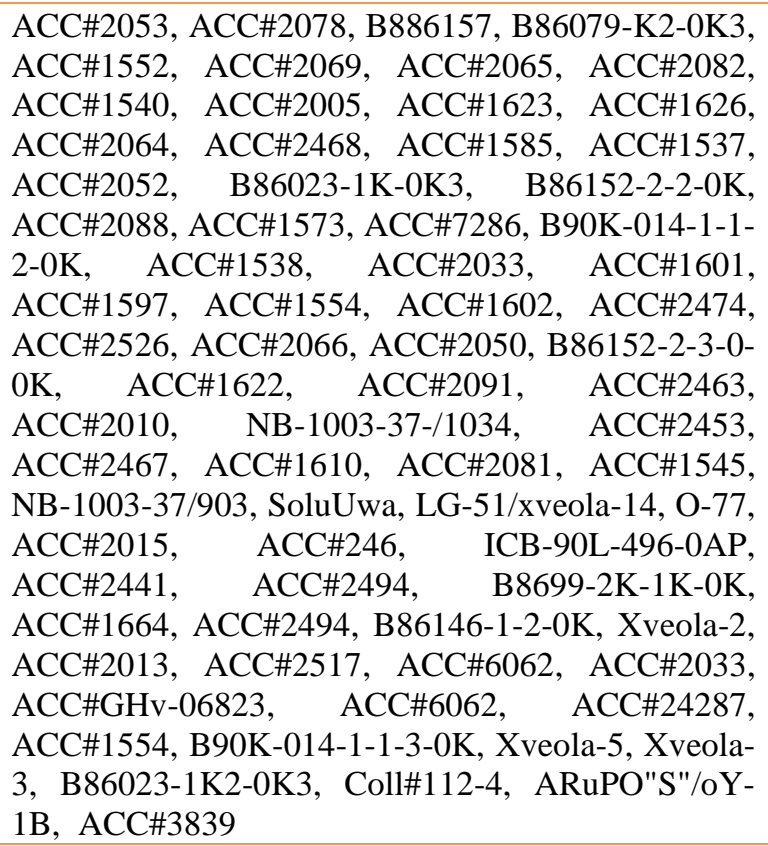 & 74 \\
\hline 6. & $\begin{array}{l}\text { Highly Susceptible } \\
\text { (HS) }\end{array}$ & $>79$ & $\begin{array}{l}\text { ACC\#1592, } \quad \text { ACC\#2662, } \\
\text { ACC\#2074 }\end{array}$ & 4 \\
\hline
\end{tabular}

Similarly, during 2018-2019, out of 108 barley genotypes, 5 genotypes were resistant, 25 were moderately resistant, 65 were susceptible and 14 were highly susceptible to the disease (Table 2, Figure 1). 
Table 2. Disease scores of barley genotypes against Bipolaris sorokiniana at National Maize Research Program, Rampur, Chitwan, Nepal during 2019 Winter

\begin{tabular}{|c|c|c|c|c|}
\hline SN & $\begin{array}{l}\text { Disease } \\
\text { Response }\end{array}$ & $\begin{array}{l}\text { Double } \\
\text { Digit } \\
\text { Scale }\end{array}$ & Barley Genotypes & $\begin{array}{l}\text { No of } \\
\text { genotypes }\end{array}$ \\
\hline 1. & Immune (I) & 00 & Nil & \\
\hline 2. & Resistant (R) & $01-14$ & $\begin{array}{l}\text { ACC 2059, ACC 2032, B-90-K-014-0-3-1-0-OK and B90K- } \\
014-1-1-3-0 K\end{array}$ & 5 \\
\hline 3. & $\begin{array}{l}\text { Moderately } \\
\text { Resistant } \\
(\mathrm{MR})\end{array}$ & $15-35$ & $\begin{array}{l}\text { ICB-90-K, ACC 2066, ACC 2067, ACC 1623, ACC 2078, } \\
\text { ACC 2088, ACC 1552, ACC 1609, XVEOLA-2, ACC 2467, } \\
\text { ACC 1620, Bonus ,ACC 1540-1, ACC 2091, ACC 1294, } \\
\text { ACC 1616, ACC 2010, BN HONA, ACC 2053, XVEOLA- } \\
\text { 28, LG-51, ACC 1563, 1G-51/XVEOLA-14, B86023-2K- } \\
\text { 0K3, ACC 5839 }\end{array}$ & 25 \\
\hline 4. & $\begin{array}{l}\text { Moderately } \\
\text { Susceptible } \\
\text { (MS) }\end{array}$ & $36-55$ & Nil & \\
\hline 5. & $\begin{array}{l}\text { Susceptible } \\
\text { (S) }\end{array}$ & $56-79$ & $\begin{array}{l}\text { ACC 1585, B86152-2-3-3-0K, ACC 2476, B90K-014-1-1-2- } \\
\text { OK-1, ACC 1573, B86146-1-2-OK, ACC 2517, B86019-1K- } \\
\text { 3K-0K3, ACC 2030, ACC 1576, ACC 1622, ACC 2497, } \\
\text { ACC 1612, B86152-2-2-OK, B86157, B86023-1K-2K-OK3, } \\
\text { ACC 1585, ACC 7286, ACC 1585, ACC 1538, ACC 16062, } \\
\text { ACC 1626, ACC 1597, ACC 2010, B86099-2K-1K-OK, } \\
\text { ACC 2069, ACC 1601, ACC 2463, ACC 2454, NB-1003- } \\
371903, \text { AC GHV-06816, ACC 1554, ACC 2005, ACC 2082, } \\
\text { ACC 1537, ACC 2526, ACC 2441, ACC 1504, Solu Uwa, } \\
\text { B86152-2-2-OK, ACC 2033, ACC 2008, ACC 2464, } \\
\text { XVEOLA-3, ACC 6062, ACC 2015, NB1003-371034, ACC } \\
2072, \text { ICB-105969-3-2-OK, ACC 1664, ACC GHV 06823, } \\
\text { ACC 2474, B86079-2K-30K, ACC 2087, ACC 2487, ACC } \\
\text { 1558, ACC 2035, ACC 2050, ICB-901-496-0AP, LO-77, } \\
\text { ACC 2087, MATTI CO"s/y" 1b-oy, ACC 2081, ACC 2052, } \\
\text { B86023-1K-0K3 }\end{array}$ & 65 \\
\hline 6. & $\begin{array}{l}\text { Highly } \\
\text { Susceptible } \\
\text { (HS) }\end{array}$ & $>79$ & $\begin{array}{l}\text { ACC 5157, ACC 1602, AROPO-"3"/OY-1B, CO11 112-4, } \\
\text { ACC 6467, ACC 1593, ACC 2063, ACC 2030, ACC 2079, } \\
\text { ACC 2453, ACC 2441, ACC 2494, ACC 2055, ACC 2496, }\end{array}$ & 14 \\
\hline
\end{tabular}

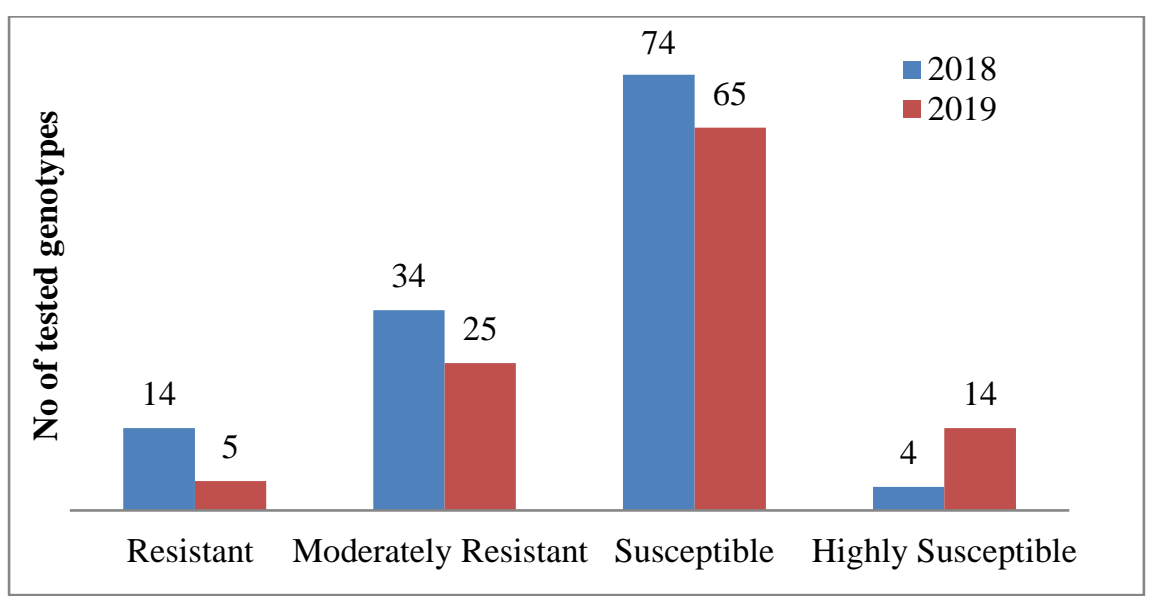

Figure 1. Barley genotypes showing different types of reactions to spot blotch disease at National Maize Research Program, Rampur, Chitwan, Nepal during 2 consecutive years 2018 and 2019.

The variation was observed for resistance and susceptibility in barley genotypes to the spot blotch disease between the years 2018 and 2019. There were slightly more resistant genotypes during year 2018 to spot blotch disease and susceptibility was increased during 2019 (Figure 1). The crop season 
of 2019 was affable for spot blotch disease development in barley and the disease severity was very high in Rampur condition.

\section{Effect of meteorological factors on development of disease}

Initially disease started from January last week and the disease severity was low and gradually increased and reached to its peak $(82.40 \%)$ on $6^{\text {th }}$ standard meteorological week (SMW) (March second week). So far as the effect of meteorological parameters is considered, the maximum disease severity $(82.40 \%)$ was recorded during $6^{\text {th }}$ SMW when corresponding weather parameters viz. maximum and minimum temperature $\left({ }^{\circ} \mathrm{C}\right)$, relative humidity $(\%)$ and rainfall $(\mathrm{mm})$ were $30.31,16.31$, 72.85 and 10.65, respectively over the years 2018 and 2019 (Table 3).

Table 3. Disease severity of spot blotch (Bipolaris sorokiniana) on barley in relation to meteorological parameters during winter season of 2018-2019 at National Maize Research Program, Rampur, Nepal

\begin{tabular}{lllllll}
\hline Month & SMW & $\begin{array}{l}\text { Spot blotch } \\
\text { DS }(\boldsymbol{\%})\end{array}$ & $\begin{array}{l}\text { Maximum } \\
\text { Temperature } \\
\left({ }^{\circ} \mathbf{C}\right)\end{array}$ & $\begin{array}{l}\text { Minimum } \\
\text { Temperature } \\
\left({ }^{\circ} \mathbf{C}\right)\end{array}$ & $\begin{array}{l}\text { Total Rainfall } \\
(\mathbf{m m})\end{array}$ & $\begin{array}{l}\text { Relative } \\
\text { Humidity } \\
(\%)\end{array}$ \\
\hline February & 1 & 11.25 & 24.64 & 10.25 & 2.00 & 88.55 \\
\hline February & 2 & 19.93 & 24.95 & 11.34 & 14.70 & 85.60 \\
\hline February & 3 & 55.45 & 26.59 & 12.90 & 0.30 & 85.35 \\
\hline February & 4 & 65.32 & 27.09 & 14.68 & 6.60 & 80.35 \\
\hline March & 5 & 72.35 & 28.89 & 15.81 & 0.00 & 75.70 \\
\hline March & 6 & 82.40 & 30.31 & 16.31 & 10.65 & 72.85
\end{tabular}

SMW- Standard Meteorological Week, DS- Disease Severity, ${ }^{\circ} \mathbf{C}$ - degree centigrade, mm- millimeter, \%-percentage

\section{Correlation among weather parameters and with disease severity}

The combined correlation analysis of disease severity with meteorological factors over the years 2018 and 2019 showed that the spot blotch disease severity (\%) had significant strong positive correlation with average maximum temperature $(\mathrm{r}=0.94)$ and average minimum temperature $(\mathrm{r}=0.98)$. The average relative humidity had significant strong negative correlation $(\mathrm{r}=-0.89)$ and total rainfall showed non-significant negative impact $(\mathrm{r}=-0.13)$ with spot blotch disease severity (Table 4$)$.

Table 4. Correlation coefficient of spot blotch disease severity on barley in relation to meteorological factors during winter season of 2018 and 2019 at National Maize Research Program, Rampur, Nepal

$$
\text { Maximum Minimum Total Rainfall Relative Disease }
$$
Temperature $\left({ }^{\circ} \mathrm{C}\right) \quad$ Temperature $\left({ }^{\circ} \mathrm{C}\right) \quad(\mathrm{mm}) \quad$ Humidity $(\%) \quad$ Severity $(\%)$

Maximum 1

Temperature $\left({ }^{\circ} \mathrm{C}\right)$

Minimum

Total Rainfall (mm)

Relative Humidity

(\%)

Disease Severity (\%) 0.94*

0.96

\section{1}

$-0.03-0.03$

$-0.03-1$

$\begin{array}{cc}-0.03 & 1 \\ -0.96 & -0.11\end{array}$

1

* Significant at $5 \%$ level of significance

\section{Multiple linear regression model}

This forecasting model relies on average maximum and minimum temperature, total rainfall and average relative humidity to assign disease severity value. This model has an adjusted $\mathrm{R}^{2}$ value of 0.99 and standard error is $0.85(\mathrm{n}=6)$. The regression equation is, Disease severity $(\mathrm{DS})=-887.05+9.28$ $\max$ temp $\left({ }^{\circ} \mathrm{C}\right)+17.03$ min temp $\left({ }^{\circ} \mathrm{C}\right)+0.35$ total rainfall $(\mathrm{mm})+5.58$ relative humidity $(\%)$. The pvalue for the full model is 0.01 which is small enough at $5 \%$ level of significance to suggest that at least one of the predictor variables may be useful for the prediction. The predicted linear regression line was displayed upward slope, ieY $=0.999 x+0.008$, with regression coefficient $R^{2}=0.99$, where ' $Y$ ' denoted predicted disease severity and ' $\mathrm{x}$ ' stood for observed disease severity per plant. The 
adjusted $\mathrm{R}^{2}$ is 0.99 which indicates that the predictor variables explain $99 \%$ of the variance in the response variable (Figure 2).

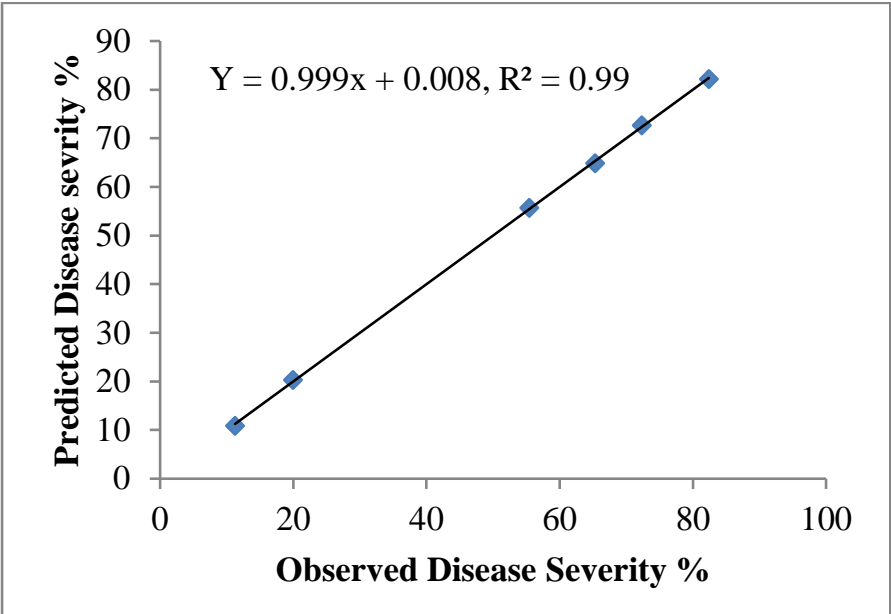

Figure 2. Observed versus predicted disease severity of spot blotch of barley as affected by meteorological factors at Rampur, Chitwan, Nepal during 2018 -2019.

\section{DISCUSSION}

Genotypes grouped as resistant had very low level of disease on plants with very small spots which were not spreading further like the susceptible genotypes. Concurrent with the present findings, it has been also reported by Jain et al (2014) who evaluated 85 barley germplasm under epiphytotic conditions and none germplasms were found immune, 68 genotypes were found resistant, 7 were moderately resistant, 7 were moderately susceptible and 3 were found susceptible. Saadi et al (2002) screened barley cultivars and found Beecher, Jimmah 59, Jimmah 54, Omani, K65 and Cooley were resistant against spot blotch. Verma et al (2013) have also reported barley genotypes, which were resistant against spot blotch. An earlier report (Hosford et al 1975) suggested polygenic control for spot blotch resistance in which three and four genes were found to control virulence of Bipolaris sorokiniana on barley genotypes NDB112 and Larker, respectively. In a study, Griffee (1925) also inferred that three unlinked genes control resistance to spot blotch at the adult plant stage.

Bailey et al (1988) reported a polygenic control for resistance to spot blotch caused by Bipolaris sorokiniana. Moderate to warm temperatures $\left(18^{\circ} \mathrm{C}\right.$ to $\left.32^{\circ} \mathrm{C}\right)$ favours the growth of B. sorokiniana. In Asia, Nema and Joshi (1973) and Singh et al (1998) reported that infection was more rapid and more severe at $28^{\circ} \mathrm{C}$ than at lower temperatures. AUDPC conducted during 26 November 2002 to 26 December 2003 for calculating the epidemiological study of disease development, increased significantly as a function of sowing time (Duveiller et al 2005). 


\section{CONCLUSION}

The findings indicate that the resistance levels as well as the number of resistant accessions are scanty in the barley germplasm material and there is none which can be termed as immune to the spot blotch in inner Tarai region of Nepal. Genotypes B86019-1K-3K 0K3, ACC\#2087, ACC\#2496, ACC\#2476, ACC\#2030, B86152-2-20K,ACC\#GHv06816, ACC\#1612, ACC\#1597, ACC\#2087, ACC\#2441, ICB-105969-3-2-0K, ACC\#2079, XVEoLA-28, ACC 2059, ACC 2032, B-90-K-014-0-3-1-0-OK and B90K-014-1-1-3-OK were found resistant against spot blotch disease in two consecutive years. These genotypes hold promise for utilization in the barley improvement for irrigated conditions having resistance to the spot blotch. All these sources are from different geographic regions/origin and may carry diverse resistance genes, making them useful for breeding program. However, their diversity at genetic level needs further confirmation by traditional inheritance studies or the molecular markers approaches.

\section{ACKNOWLEDGEMENTS}

Thanks to National Maize Research Program, Rampur and Hill Crop Research Program, Kabre team and plant pathologists of Nepal Agricultural Research Council for their valuable suggestions, continuous support and facilities during experimentation period. The fund for this study was achieved from NARC.

\section{REFERENCES}

Aggarwal PK, KK Talukdar and RK Mall. 2000. Potential yields of rice- wheat system in the Indo-Gangetic Plains of India. Consortium paper series 10. Rice-wheat consortium for the Indo-Gangetic Plains, New Delhi, India.

Bailey KL, DR Knott and H Harding. 1988. Heritability and inheritance of resistance to common root rot (Cochlibolus sativus) in wheat (Triticum aestivum). Canadian Journal of Plant Pathology 12:207-214.

Duveiller E, YR Kandel, RC Sharma, SM Shrestha. 2005. Epidemiology of foliar blights (spot blotch and tan spot) of wheat in the plains bordering the Himalayas. Phytopathology 95: 248-256.

FAOSTAT. 2017. Crops/Regions/World List/Production Quantity for Barley, 2016" UN Food and Agriculture Organization Corporate Statistical Database. http://www.fao.org/faostat/en/\#data/QC.

Griffee F. 1925. Correlated inheritance of botanical characters in barley and the manner of reaction to Helminthosporium sativum. Journal of Agriculture Research 30:915-933.

Gupta PK, R Chand, NK Vasistha, SP Pandey, U Kumar, VK Mishra and AK Joshi. 2017. Spot blotch disease of wheat: the current status of research on genetics and breeding. Microbiology 57:934-942.

Hosford RM, GRM JrSolangi and RL Kiesting. 1975. Inheritance in Cochiliobolus sativus. Phytopathology 65: 699-703.

Horsfall JG and EB Cowling. 1978. Pathometry: The measurement of plant disease. In: Plant Disease (JG Horsfall, E. Cowling, eds). 2:19-36. New York: Academic. 436p.

Jain NR, R Malik, R Selvakumar, V Pande and RPS Verma. 2014. Screening of Barley germplasm for leaf blight. Bipolaris sorokiniana) resistance. Indian Journal of Agricultural Research 48(1):67-71.

James WC. 1974. Assessment of plant disease and losses. Ann. Rev. Phytopathol. 12:27-48

Manandhar HK, RD Timila, S Sharma, S Joshi, S Manandhar, SB Gurung, S Sthapit, E Palikhey, A Pandey, BK Joshi, G Manandhar, D Gauchan, DI Jarvis and BR Sthapit. 2016. A field guide for identification and scoring methods of diseases in the mountain crops of Nepal. NARC, DoA, LI-BIRD and Bioversity International, Nepal. 183p.

Mathre DE. 1997. Compendium of barley diseases. The American Phytopathological Society, St. Paul, MN, USA.

MOAD. 2017. Statistical information on Nepalese Agriculture. Agri statistics Section, Singha Durbar, Kathmandu, Nepal.

Mujeeb-Kaji A, RL Villareal, LI Gilchrist and S Rajaram. 1996. Registration of five wheat germplasm lines resistant to Helminthosporium leaf blight. Crop Science 36:216-217.

Nagarajan S. 1998. DWR leaf blight screening nursery. Progress Report, 1998. CP 5:44.

Nema KG and LH Joshi. 1973. Spot blotch disease of wheat in relation to host age, temperature and moisture. Indian Phytopathology 26:41-48

Poehlman JM. 1994. Breeding barley and oats. In: Breeding field crops (JM Poehlman, ed). Iowa State University Press, Ames, Iowa; pp.378-420.

Riley KW and KM Singh. 1991. Diversity and Stability of Barley in Nepal. Retrieved on 24 march, 2018 from https://en.wikipedia.org/wiki/Barley 
Saadi AM, ML Deadman and AY Maskari. 2002. Screening of Wheat and Barley varieties for resistance to Spot blotch disease. Tests of agrochemicals and Cultivars 23:16-17.

Saari EE and JM Prescott. 1975. A scale for appraising the foliar intensity of wheat diseases. Plant Disease Reporter 59:377-380.

Singh RV, AK Singh, R Ahmad and SP Singh. 1998. Influence of agronomic practices on foliar blight, and identification of alternate hosts in rice-wheat cropping system. In: Helminthosporium Blights of Wheat: Spot Blotch and Tan Spot (E Duveiller, HJ Dubin, J Reeves, AMcNab, eds). CIMMYT, Mexico DF, pp.346-348.

Singh S, H Singh, A Sharma, M Meeta, B Singh, N Joshi, P Grover, A Al-Yassin and S Kumar. 2014. Inheritance of spot blotch resistance in barley (Hordeum vulgare L.). Canadian Journal of Plant Science 94:17. DOI: http://10.4141/CJPS2013-153

Verma RPS, DP Singh, R Selvakumar, R Chand, VK Singh and AK Singh. 2013. Resistance to Spot blotch in Barley Germplasm. Indian Journal of Plant Genetic Resources 26(3):220-225.

Wiese MV. 1987. Common (Dryland) root and foot rot and associated leaf and seedling diseases. Compendium of wheat diseases. American phytopathological society, st. paul, MN, pp.53-55.

Zohary D and M Hopf. 2000. Domestication of Plants in the Old World: The Origin and Spread of Cultivated Plants in West Asia, Europe, and the Nile Valley (3rd ed). Oxford University Press; pp.59-69. 